\title{
WELFARE STATES UNDER PRESSURE: CASH BENEFITS IN EUROPEAN WELFARE STATES OVER THE LAST TEN YEARS
}

\author{
Mary Daly, Georg-August Universität, Göttingen, Germany
}

Summary

This article devotes itself to an examination of the substance of reform in European welfare states over the course of the last 10 years. Its objective is mainly empirical, to compare how cash transfers in the 15 member states of the European Union as well as Norway have fared over the decade. While the article is not theory-focused, consideration of some of the wider implications of the change process which is underway is a priority. It is especially important to examine not only how the procedures and principles governing benefits have altered but whether and how change is systematically patterned across welfare states. We shall observe that pensions, unemployment benefits, parental leave and payments for the care of ill, elderly and incapacitated people have been the main focus of policy activity. As a story of both cut-backs and expansion suggests, simplistic notions of convergence or divergence are not adequate to capture what is happening. The last part of the article considers how we might make our analytical frameworks equal to the richness of the reform process which is under way.

\section{Résumé}

LES ETATS-PROVIDENCE SOUS

PRESSION: LES PRESTATIONS EN

ESPECES DES ETATS-PROVIDENCE

EUROPÉENS AU COURS DE LA

DERNIÈRE DÉCENNIE

Cet article examine la teneur de la réforme dans les Etats-providence européens au cours des dix dernières années. Son objectif, d'ordre essentiellement empirique, consiste à comparer l'évolution des transferts d'espèces dans les quinze pays membres de l'Union européenne ainsi qu'en Norvège. Quoique l'article ne se concentre pas sur la théorie, il accorde une attention prioritaire à l'observation de certaines conséquences plus générales du processus de changement en cours. Il est particulièrement important d'examiner non seulement la manière dont les procédures et principes régissant les prestations se sont modifiés mais également si et comment les changements se sont modelés systématiquement d'un Etatprovidence à l'autre. Nous observerons que les politiques mises en cuvre se concentrent avant tout sur les retraites, les allocations chômage, les congés parentaux et les rétributions pour les soins aux personnes malades, âgées et frappées d'incapacité. Une histoire faite à la fois de réductions et d'expansion donne lieu de penser que les notions simplistes de convergence ou de divergence ne conviennent pas pour comprendre les faits. La dernière partie de l'article cherche à savoir comment ramener nos cadres analytiques à la hauteur de la richesses du processus de réforme en cours. 


\section{Introduction}

Welfare states are always out of date. For one, demographic and social developments continually undermine the 'model units' around which benefit systems grant or debar access. For another, economic and social changes generate new needs and risks which only with time, if ever, achieve legitimacy as grounds for income replacement. But above and beyond these tendencies, there are some historical periods when the very modes of integration which underpin welfare states are challenged. Simply put, some periods squeeze welfare states tighter than others. The last decade always appears to be particularly momentous. Are we entitled to make special claims for the 10 years joining 1985 with 1995? True, they were witness to a particular configuration of political and economic circumstances. This was the decade when high unemployment came to be accepted as a seeming constant, however unwanted, on the economic landscape of Western Europe. In addition, the unrelenting financing shortages together with the ever more apparent rigidities of national welfare arrangements made welfare state benefits and services an attractive offering on the altar of reform. What was the significance of the last decade in terms of welfare state reform and how have cash support systems emerged from the fray?

This article sets out in search of some of the contemporary history of Western European welfare states. Its focus is on how cash transfer systems in the 15 member states of the European Union as well as Norway have been reformed in the last 10 years. While changes in benefit provision are interesting in themselves - and it is these which provide the empirical foundation of the article - I also want to consider the implications of emerging welfare state reforms within the context of the signifcance of different systems of welfare. Two sets of questions, then, drive the work: first, what has been happening to welfare state cash benefits over the last decade?; second, how might we evaluate the developments in terms of national and cross-national patterns and their transition? To answer the first question we must cut a path through the myriad of changes made to cash benefits so as to identify those which signify trends over time. The article's second task requires analysis of both the main implications of developments and an overview in terms of cross-national patterns. This should be approached with care for trends do not come ready packaged and labelled. In addition, as Myles (1990) points out, large historical shifts tend to be accretions of many small changes which are difficult to detect empirically. And, should we succeed in observing them, their significance is not self-evident: they could represent an emerging institutional settlement but alternatively they may be no more than a blip in a cycle. Mindful of the difficulties of identifying real shifts, my aims are modest - to examine how cash benefits are being altered in practice and to consider some implications for our analytical frameworks.

The first section of this article briefly discusses the specific focus of enquiry and how the topic will be approached. The second and main part proceeds to identify the general patterns of reform and the specific programmes which have been most affected. To end, some of the implications of the reforms for welfare state scholarship are drawn out.

\section{The comparative framework}

Even though we have been talking about a 'crisis' of the welfare state now for 20 years, a literature on welfare state change and transformation has been slow to accumulate. The weaknesses of the major theoretical approaches are never more manifest than when we seek their help to configure emergent welfare state trajectories or to explain change. As a result, it is far from easy to put together a scenario of change from existing scholarship. One approach which is distinctive in taking 
transition as its starting point is post-Fordism (Jessop, 1988; Jessop et al., 1991; Burrows and Loader, 1994). This family of paradigms views the restructuring of welfare as part of a search for new modes of accumulation and regulation. Global pressures towards flexibilization set in train a complex displacement of national state powers, upwards, downwards and outwards, leading to a 'hollowed out' state form, the social elements of which serve the function of promoting innovation and competitiveness. Post-Fordism offers much insight into the kind of industrial order we are leaving behind and, rightly, draws attention to the way in which flexibilization of the international economy undermines the Keynesian welfare state settlement (as well as its various forms of 'after life'). The theory's subordination of welfare policy to economic imperatives arouses a sense of disquiet though. Furthermore, one of the greatest question marks hanging over the post-Fordist approach is its capacity to deal with variation. Its undoubted strengths in giving theoretical space to processes located in the international economy have their flip side in the underspecification of what we might call 'national nuance' and cross-national variation (Daly, 1997). Only one trajectory of change is really developed. Such rigidities are not very helpful to the present purpose and in any case the existing empirical information suggests that welfare restructuring is occurring along more ambiguous lines than is allowed for in the postFordist model (Burrows and Loader, 1994; Carter and Rayner, 1996). Instead of closing off options, one needs to bear all possibilities in mind for, as Frank Castles (1994: 21) rightly points out, to compare welfare states is to locate the nature of their variety.

Failure to incorporate variation is a charge which cannot be levelled at the second set of relevant literature: that on welfare state regimes. Variation is the raison d'etre of this body of work, welfare state heterogeneity its leitmotiv (albeit that all welfare states are said to be understandable in terms of a relatively small number of base models). If welfare states come in types then it is reasonable to expect systematic variation in both the pressures to which they will be subjected and the responses which such pressures will call forth. EspingAndersen (1990), for example, identifies the diverging interests of public- and private-sector workers as the axis of future citizenship struggle in the Scandinavian welfare states. The major source of pressure in the Continental European states he predicts to be the insider/outsider divide arising from labour market participation, while increasing polarization within class groups is the decisive source of cleavages in the welfare states identified as 'liberal'. Given such pressures, how are welfare states likely to respond? This remains more or less an open question, and the contribution which the regime approach can make to answering it is not self-evident. Nonetheless, the scholarship around regimes, however controversial, has one main advantage in the present context: it provides a way of organizing the analysis, of moving beyond the detail of provision in so many individual countries. While the designation of some nations and some regime types is controversial, most analysts would agree that the differences and similarities among European welfare states are such that one can speak of a Continental model, a Nordic model and two other less easily definable models which include Great Britain (and to a lesser extent Ireland) on the one hand, and the southern countries of Portugal and Spain (and perhaps Italy and Greece) on the other. Although there is undoubtedly a research agenda around establishing whether particular regime types hold when changes and transformation are the focus of analysis, I use the regime types idea mainly as a tool to guide the search for and organization of common patterns among groups of countries.

Moving on to the analysis proper, as Hagen (1992: 130) points out, any comparison of social security programmes across countries (and/or time) is faced with two major questions: what is to be the basis of comparison and on which criteria is the analysis to rest. In 
regard to the first, I will identify relevant welfare state trends by focusing upon changes in cash benefit systems. How do I justify reducing welfare states to their cash benefit systems? At least part of their appeal is their power to reveal the nature and quality of social rights. As the most tangible expression of social rights, cash transfers are wonderfully revealing of the terms on which individuals can make claims on public resources and the types of solidarities which are fostered by systems of public support. They offer a rich field of interpretation. There is probably no better way to uncover how the state stacks individuals and groups vis-a-vis each other on the resources' hierarchy. Cash transfers, furthermore, lead to the heart of welfare states' objectives, variation in benefit height, type and general organization allowing us to judge the relative priority attributed to poverty alleviation, income security and income redistribution. Of course, cash transfers comprise only one part of welfare states' activities. Service provision and taxation are also central. Regrettably, neither social services nor taxes can be covered in the present analysis, although their importance is recognized. The second methodological issue concerns the building blocks for the comparison. In this regard I am going to focus upon the institutional architecture of cash benefit systems. My concern lies, therefore, with programmatic features of cash benefits such as rules of entitlement, the scope, height and duration of benefits, and so on. By enquiring about whether and how these have been altered through legislation over the last 10 years, we can discover change in how people get access to benefits, the conditions under which they remain within the public support system and for how long they are allowed to rely on its resources.

With 16 countries in the analysis, charting the changes is a very big undertaking; one which forces me to neglect many of the finer points of reform in individual welfare systems. Furthermore, such a large number of countries heightens the risk of misinterpretation since programmes are removed from their national setting. But there are always trade-offs and some complexities I am prepared to forego on this occasion so as to obtain a European overview. It goes without saying that the type of pan-European enquiry undertaken here needs to be supplemented by research which locates provisions and trends within their national context.

\section{Main changes in cash benefits since 1985}

\section{Welfare state expenditure and benefit provision: the background}

The last decade has been a period of both welfare state cut-back and expansion. Considered in terms of total social expenditure as a percentage of GDP, Belgium and Ireland have made absolute cut-backs since 1985, while France, Greece, Luxembourg and the Netherlands have held spending more or less steady. In point of fact though, social spending has been more often on the rise in Europe over the last 10 years than on the decline, with Denmark, Finland, Spain and Sweden, as well as Italy, Portugal and the United Kingdom, seeing a considerable hike (European Commission, 1995: 61). Higher expenditure is but infrequently associated with programme expansion. Only the southern European countries are spending more money on cash benefits because they are expanding their basic systems of social protection (albeit to a varying degree). More often than not throughout the 16 nations, social expenditure is growing because of an increasing number of benefit claimants which is itself a function of the progressive ageing of Europe's population and the persistence of high unemployment.

A discourse of crisis is everywhere and the lexicon of reform is now familiar: 'targeting', 'incentives/disincentives', 'flexibility', 'selectivity' and the ubiquitous 'cost containment' are the themes through which the need for and 
proposed content of reforms are rehearsed. But the rhetoric around the welfare state is considerably more daring than the reality of what passes into legislation. In actual fact, European countries rely on a relatively narrow band of reform strategies. One can, following the European Commission (1995: 14), group the approaches which have been taken to reform as follows:

1. restricting access to benefits by attaching additional conditions and tightening regulations

2. increased targeting of transfers by greater use of means-testing, the linking of the size of benefits to income and by making benefits taxable

3. increased privatization, not only in terms of contracting out of services to the private sector but also by according greater responsibility to individuals to provide for their own protection against risks, or to family members to provide financially for each other

4. heightened, and growing, emphasis on active measures to get people into employment so that they can support themselves.

These trends have a mirror image on the financing side where efforts have intensified to reduce the costs to employers and to seek alternative forms of funding for social protection. Increased funding through taxation (although Denmark and Sweden display something of a counter trend in taking steps towards contributions) and altering the division of funding responsibilities between national and regional/local levels have been the favoured strategies. Overall, financing problems have tended to be resolved by making cuts in benefits rather than by seeking alternative means through which to increase the resources available to social security (Ploug and Kvist, 1994: 17).

Reforms have not been implemented uniformly across countries, however, nor within them in terms of programme areas. In times of retrenchment, some programmes have even become more deeply institutionalized - one of the most notable examples being maternity benefits which have, thus far at any rate, not only escaped the hatchet but enjoyed an improvement in generosity and conditions. Taking an overview of developments throughout the 16 countries, three programmatic areas have been at the centre of policy attention over the last decade: ${ }^{1}$

(1) old-age pensions

(2) unemployment benefits

(3) provisions related to caring for young children and/or ill, elderly or handicapped children and adults.

One could say, then, that the broader referents of change have been the boundaries between the state and the market on the one hand and those between the state and the family on the other. Which particular aspects of programmes are being altered?

\section{Old-age pensions and retirement}

In terms of cost and coverage, pensions are among the most contentious of all benefits. They can almost single-handedly precipitate a funding crisis accounting as they do for such a large proportion of welfare state expenditure, and they are at the same time politically volatile because they affect the financial wellbeing of so many people. Yet to judge by the extent of policy activity under way, reformminded politicians and administrators in most countries are unable to resist the temptation of tampering with pensions (Table 1). Looking at developments over the course of the last decade, one can speak of a general trend of convergence in European pension systems. Two patterns form the heart of this convergence: a lengthening of the period to be spent in employment and a reduction in the average generosity of pensions (Table 1). With reference to the first, European nations are levelling up and in the second regard they are levelling down. 
Table 1 Main trends in relation to old-age pensions during the last decade ${ }^{\mathrm{a}}$

Austria The calculation period for the pension was changed from the last 5 years (between 1985 and 1987) to the last 10-15 (between 1988 and 1992) to the best 15 years in 1993; a law of 1992 ordained that the pension age will be equalized for women and men, women's official retirement age rising from 60 in small steps to 65 between 2018 and 2032 .

\begin{tabular}{|c|c|}
\hline Belgium & \\
\hline Denmark & $\begin{array}{l}\text { In the mid-1980s an earnings test was introduced for the basic amount of the pension for those aged } \\
\text { between } 67 \text { and } 70 \text {; in } 1994 \text { this earnings or retirement test was extended to all pensioners. }\end{array}$ \\
\hline Finland & $\begin{array}{l}\text { An employee contribution (a special tax of } 3 \% \text { of wages) for occupational pensions was introduced in } \\
1993 \text {; the maximum pension for public-sector workers was reduced by } 5 \% \text { (from } 65 \% \text { to } 60 \% \text { ); the } \\
\text { official retirement age of public-sector workers was increased from } 63 \text { to } 65 \text { (to match the private } \\
\text { sector). }\end{array}$ \\
\hline France & $\begin{array}{l}\text { From } 1994 \text { the amount of the pension was to be made dependent (progressively up to the year 2008) } \\
\text { on the best } 25 \text { years of earnings (from the best } 10 \text { ); the number of years of contribution for a full } \\
\text { pension was to be increased up to the year } 2003 \text {, from } 37.5 \text { to } 40 \text {. }\end{array}$ \\
\hline Germany & $\begin{array}{l}\text { Reforms introduced in } 1992 \text { will gradually increase the retirement age for women from } 60 \text { to } 65 \text { and } \\
\text { for men from } 63 \text { to } 65 \text {. }\end{array}$ \\
\hline Greece & $\begin{array}{l}\text { In } 1992 \text { the lower levels of pension were significantly increased and the age of retirement raised for } \\
\text { women to } 65 \text {. }\end{array}$ \\
\hline eland & \\
\hline Italy & $\begin{array}{l}\text { From } 1995 \text { it is planned to move progressively by the year } 2008 \text { to a flexible situation where both } \\
\text { women and men can retire any time between } 57 \text { and } 65 \text { (women currently } 57 \text { and men } 65 \text { ); benefits } \\
\text { are to be made dependent on contributions rather than earnings; housewives can belong to a new } \\
\text { voluntary, but subsidized, pension scheme. }\end{array}$ \\
\hline \multicolumn{2}{|l|}{ Luxembourg } \\
\hline etherlands & $\begin{array}{l}\text { In } 1985 \text { married women were granted the right to claim the statutory pension in their own right; in } \\
1987 \text { an extra allowance for the younger partner, dependent on his/her income, was introduced into } \\
\text { pensions, splitting the pension into a basic amount of } 70 \% \text { (of the minimum wage) for the main } \\
\text { recipient with a } 30 \% \text { supplement possible for the spouse depending on means; in } 1994 \text { the allocation } \\
\text { was changed to } 50: 50 \text {. }\end{array}$ \\
\hline Norway & $\begin{array}{l}\text { In } 1992 \text { an earnings test was introduced for pensions to those between the ages of } 67 \text { and } 70 \text {, } \\
\text { replacing an earlier condition of retirement; in } 1992 \text { the income ceiling for the earnings-related } \\
\text { second tier of public pensions was lowered and the pension ratio reduced from } 45 \% \text { to } 42 \% \text {. }\end{array}$ \\
\hline Portugal & $\begin{array}{l}\text { In } 1994 \text { the amount of the pension was made dependent on the best } 10 \text { of the past } 15 \text { years of } \\
\text { earnings (from the best } 5 \text { of the last 10); in } 1994 \text { also, the basic pensions were significantly increased; } \\
\text { from } 1994 \text { the age of retirement for women is being progressively raised (by six months each year) } \\
\text { from } 62 \text { to } 65 \text {. }\end{array}$ \\
\hline Spain & $\begin{array}{l}\text { In } 1985 \text { the minimum period of compulsory contributions necessary for pension entitlement was } \\
\text { raised from } 10 \text { to } 15 \text { years and the amount of pensions was to be calculated on the last } 8 \text { years } \\
\text { instead of the last } 2 \text {; in } 1991 \text { a guaranteed minimum amount of non-contributory pension was } \\
\text { introduced. }\end{array}$ \\
\hline Sweden & $\begin{array}{l}\text { From } 1991 \text { early retirement pensions were no longer available on labour market grounds; in } 1993 \text { the } \\
\text { basic amount for calculating the pension was reduced by } 2 \% \text {; from } 1993 \text { a gradual raising of the } \\
\text { retirement age from } 65 \text { to } 66 \text {; from } 1995 \text { pensions more directly linked to contributions. }\end{array}$ \\
\hline $\begin{array}{l}\text { United } \\
\text { Kingdom }\end{array}$ & $\begin{array}{l}\text { Since } 1986 \text { there have been greater incentives to drop out of the supplementary state pension } \\
\text { scheme; it is planned to bring the retirement age of women (now 60) progressively into line with that } \\
\text { of men (65) by the year } 2020 \text {; from } 1999 \text { the supplementary public pension will be calculated on } \\
\text { lifetime earnings rather than the best } 20 \text { years. }\end{array}$ \\
\hline
\end{tabular}

Note: ${ }^{a}$ Changes such as uprating of the benefits and minor alterations in either the conditions of entitlement or administration/delivery are not included here. 
Lengthening the period to be spent in employment can be brought about by either raising the official age of retirement or extending the duration of contributions necessary for either a minimum or maximum pension. Both are popular, especially the former. In six countries the official age of retirement has either been raised or is in the process of so being. In Austria, Germany, Greece, Italy, Portugal and the United Kingdom (and in Finland for workers in the public sector), moves are under way towards a standardization over the next 20 or so years of the retirement age for both women and men at 65 years. Sweden also is raising its retirement age from the current threshold of 65 years to 66 (bringing it more into line with the official cut-off at 67 years of its Danish, Icelandic and Norwegian neighbours). The second strategy for pushing retirement further back in the life phase is to lengthen the contribution period required for a (minimum or full) pension. This has happened in France, where the number of years of contributions required for a full pension has been raised (from 37.5 to 40 ); and in Spain, as regards the period required for the minimum pension (raised from 10 to 15 years). Lengthening the required contribution period is in fact a long-term trend. Palme (1990: 53) tells us that in 1985,26 years were needed to get a full pension in OECD countries whereas an average contribution period of 13 years sufficed in 1960. Today the requirements are even more demanding: within the $\mathrm{EU}$ at present the number of contribution years required for a full pension varies between a minimum of 35 (Spain and Greece) and 48 (Ireland).

Lengthening the period to be spent in employment is a considerable turnabout compared with the policy emphasis of the 1970 s and most of the 1980 s which promoted a shorter working life (some cross-national variation notwithstanding). Pension reforms put in place over the last 10 years represent a general reversal of that policy, the about-turn being especially marked for France and Germany. Such reforms are driven in the main by efforts to contain expenditure on pensions, the former programmes encouraging early, mainly male, retirement having proved too popular and too costly. But there was also another impulse underlying the reforms: equalizing the retirement age for women and men. Hence, gender equality considerations provided the key push towards lengthening the average working life in Austria, Greece, Italy, Portugal and the United Kingdom.

The second strategy for pension reform over the last decade has centred upon reducing the value of pensions. Both direct and indirect measures have been deployed towards this end. One of the most common courses pursued was to increase means-testing or earnings-testing for the purposes of access to and height of pensions. All the Scandinavian countries are represented here as is the Netherlands. However, the developments in Denmark and Norway represent tests of retirement rather than of income per se, and they are not radically new departures but rather a widening of existing practice. A more indirect way of reducing the average height of pensions is to extend the period of 'best years' against which the amount of the pension is to be calculated. Austria, France, Portugal, Spain and the United Kingdom have each taken steps in this direction over the last 10 years. It is noteworthy that women are much more likely than men to be adversely affected by this general move away from what is a 'woman-friendly' component of pensions.

The conclusions to be drawn about the pension-related developments over the last decade depend on the point of analysis. If we orient ourselves to the nature of social rights, the conditions under which people gain access to pension entitlements have been significantly altered. Europeans will have to work longer for lower pensions which means among other things that exit from the labour market must be postponed for as long as possible. ${ }^{2}$ However, if one uses institutional or programmatic characteristics as the gauge of change, then it would be difficult to argue that 'pension regimes' have actually been transformed throughout Europe. 
Certainly it is becoming harder to get a pension, especially a 'good' one, but limiting the size of pensions and altering some of the conditions of access do not necessarily amount to a transformation of the basic structure of the pension system itself. Only in the United Kingdom and the Netherlands could farreaching structural changes be said to have taken place, with the virtual 'privatization' of pensions in the former and the alteration of the principle of entitlement (largely to give women an individual right) in the latter. There are two general trends running through pension reforms across countries. First, instead of statutory pensions becoming more flexible, and hence more in line with received wisdom about globalization and postindustrialism, they are in fact becoming less flexible. Secondly, the statutory age of retirement is waning in importance compared with the number of required contribution years as the height of pensions is ever more closely tied to the contributions paid.

\section{Benefits for the unemployed}

The potential for variation in policies on unemployment is very large. As Clasen (1994: 13) points out, no other income-maintenance scheme is influenced by such a wide range of public policies (e.g. economic, fiscal, labour market and social policies). One way of making sense of this policy domain is to differentiate between policies which attempt to counter unemployment and those which seek to provide for the unemployed. While the focus here is on the latter, ${ }^{3}$ the backdrop to any changes which have been made in benefits for the unemployed is a general shift away from what the European Commission terms 'passive policies of income support' towards 'active measures to enable people to be self-supporting' (1995: 16). This means policies which offer incentives for people to take up employment and/or contain strong disincentives for them to remain on the benefit lists. Benefits for the unemployed, more than any others, are surrounded by conjecture about work incentives and fraud or abuse. Such concerns have been accompanied in many European countries by more proactive employment policies, operationalized by, inter alia: increased public employment services to provide jobseekers with help and advice; the legalizing of private placement agencies in Sweden in 1993, and in Germany and Austria in 1994; and the signifcant expansion of wage subsidies in Denmark, Finland, France, Germany and Sweden (ibid: 49-51).

But parallel to this expansion of 'active' measures, the height or size of cash payments to the unemployed has been, for at least a decade now, contentious. One can observe a general tendency on the part of most of the countries in Europe to continue to tighten conditions of access to unemployment benefits and to avoid rates of support which might act as disincentives to employment (Table 2). All the usual suspects have been deployed. The value of benefits has been lowered in Austria, Finland, France, Germany, Spain and Sweden; waiting periods have been introduced or lengthened in Sweden and Belgium; there has been a general tightening of the rules around accepting offers of employment in Finland and the United Kingdom; the required periods of labour market participation have been lengthened in both the Netherlands and the United Kingdom; and in the latter country the forward march of means-testing has meant that, since 1996, the unemployed can receive a nonmeans-tested-benefit for no longer than six months. Clearly, retrenchment is the dominant welfare state response to stubbornly high unemployment. But it is not the only one.

Denmark in 1992 and Finland in 1994 introduced new income transfers for the unemployed. The Danish provision comprised a 'transition allowance' in the form of a payment for early retirement, available to unemployment fund members aged between 55 and 59. In 1994 the duration of entitlement to unemployment benefits was extended to seven years and it was made possible for unemploy- 
Table 2 Main trends in relation to old-age pensions during the last decade ${ }^{\mathrm{a}}$

\begin{tabular}{|c|c|}
\hline Austria & $\begin{array}{l}\text { In } 1988 \text { the duration of unemployment benefit was extended and in that year also married women } \\
\text { were granted access to the second, means-tested tier of unemployment support; in } 1989 \text { the waiting } \\
\text { period for young unemployed was reduced; in } 1990 \text { the replacement rate for unemployment benefit } \\
\text { was made a fixed proportion of net income for all income groups (then } 57.9 \% \text { now } 56 \% \text { ); in } 1995 \\
\text { the special preretirement benefit funded by the unemployment insurance was abolished. }\end{array}$ \\
\hline Belgium & $\begin{array}{l}\text { There has been an increase in the waiting period for receipt of the benefit by young people; } \\
\text { possibilities to retain benefit while taking up employment were increased in } 1994 \text {. }\end{array}$ \\
\hline Denmark & $\begin{array}{l}\text { In } 1993 \text { a new transitional benefit was introduced for unemployed people aged between } 55 \text { and } 59 \text {; in } \\
1994 \text { the period of possible entitlement to unemployment benefit was extended to } 7 \text { years, divided } \\
\text { into one period of } 4 \text { years and a second of } 3 \text { years - for benefit receipt in both periods job } \\
\text { activity/training was made mandatory. }\end{array}$ \\
\hline inland & $\begin{array}{l}\text { In } 1985 \text { unemployment benefits were made taxable and the replacement level was raised from } 75 \% \text { of } \\
\text { wages to } 90 \% \text {; in } 1992 \text { the earnings-related element in unemployment benefit was reduced by } 3 \% \text {; a } \\
\text { new means-tested benefit for the unemployed was introduced in } 1994 \text {, to provide further income } \\
\text { maintenance to those unemployed persons looking for employment. }\end{array}$ \\
\hline France & $\begin{array}{l}\text { From } 1992 \text { the size of the benefit was to be reduced every } 4 \text { months (by } 15 \% \text { to } 25 \% \text { each time) and } \\
\text { a waiting period was introduced. }\end{array}$ \\
\hline Germany & $\begin{array}{l}\text { In } 1985 / 6 \text { the duration of benefit entitlement was extended for those aged over } 44 \text { and general } \\
\text { conditions of access were eased; in } 1994 \text { benefits were cut by between } 1 \% \text { and } 3 \% \text { and the duration of } \\
\text { the special social assistance benefit for the unemployed was limited in certain circumstances to } 1 \text { year. }\end{array}$ \\
\hline Greece & $\begin{array}{l}\text { In } 1985 \text { benefits for young unemployed people, aged between } 20 \text { and } 24 \text { years, were introduced; } \\
\text { married women have been able to claim unemployment benefit in their own right since } 1985 \text {. }\end{array}$ \\
\hline Ireland & $\begin{array}{l}\text { In } 1986 \text { the absolute bar on women claiming the means-tested unemployment payment was lifted } \\
\text { plus unemployment benefit was to be payable to women for the same duration as to men; in } 1994 \text { the } \\
\text { earnings-related component of the social insurance unemployment payment was abolished but the } \\
\text { value of benefits was raised by } 10 \% \text {. }\end{array}$ \\
\hline Italy & $\begin{array}{l}\text { In } 1990 \text { unemployment benefit was made earnings-related (a } 15 \% \text { replacement rate); in } 1991 \text { the } \\
\text { replacement rate was raised to } 20 \% \text { and in } 1993 \text { to } 25 \% \text {. }\end{array}$ \\
\hline \multicolumn{2}{|l|}{ Luxembourg } \\
\hline Netherlands & $\begin{array}{l}\text { From } 1987 \text { a longer period of employment was required before a claim for benefit could be made and the } \\
\text { duration for which benefits could be received was reduced; in that year also the status of breadwinner as } \\
\text { a condition of entitlement for benefits was eliminated and credits for carers introduced; in } 1995 \text { the } \\
\text { conditions of access for unemployment benefit were tightened: instead of } 26 \text { weeks of employment over } \\
\text { the last } 52 \text { weeks, } 26 \text { within the last } 39 \text { became necessary and for the additional benefit the number of } \\
\text { years necessary in employment was raised from } 3 \text { to } 4 \text { out of the last } 5 \text {; under certain conditions the } \\
\text { benefit paid is calculated as a proportion of the legal minimum wage rather than actual wages. }\end{array}$ \\
\hline Norway & The qualifying conditions for unemployment compensation have been liberalized since 1990. \\
\hline Portugal & $\begin{array}{l}\text { An unemployment allowance was introduced in } 1989 \text { ( } 65 \% \text { wage replacement rate for a maximum of } \\
30 \text { months). }\end{array}$ \\
\hline Spain & $\begin{array}{l}\text { In } 1992 \text { the minimum period required for entitlement increased from } 6 \text { to } 12 \text { months; in } 1994 \\
\text { unemployment benefit was made taxable and reduced in value to } 75 \% \text { of the minimum wage. }\end{array}$ \\
\hline Sweden & $\begin{array}{l}\text { In } 1994 \text { unemployment insurance was made mandatory (but was changed back to being voluntary in } \\
\text { 1995); in } 1994 \text { also benefits were cut by } 10 \% \text { to } 80 \% \text { of previous earnings and a further cut of } 5 \% \\
\text { was implemented in 1996; a waiting period of } 5 \text { days was also introduced. }\end{array}$ \\
\hline $\begin{array}{l}\text { United } \\
\text { Kingdom }\end{array}$ & $\begin{array}{l}\text { From } 1988 \text { entitlement to unemployment benefit has been tied more closely to recent } \\
\text { employment; in } 1989 \text { an 'actively seeking work' test was introduced; in } 1996 \text { a new benefit - Job } \\
\text { Seeker's Allowance - replaced unemployment benefit, involving greater means-testing and abolishing } \\
\text { the supplement for the adult dependant of the recipient. }\end{array}$ \\
\hline
\end{tabular}

Note: a Changes such as uprating of the benefits and minor alterations in either the conditions of entitlement or administration/delivery are not included here. 
ment benefit to continue after the age of 50 without falling out of the social insurance system. ${ }^{4}$ Policy in Finland has been, compared with Denmark, somewhat less generous towards the unemployed. A new allowance was also introduced there to cope with the huge growth in unemployment but it is meanstested and has a time limit of 180 days. But apart from Sweden, the Scandinavian response to what is for this group of countries a relatively new experience of high unemployment has been expansionary. There are also other examples of policy expansion in provision for the unemployed over the last decade: a new scheme was introduced in Greece in 1985 for unemployed young people; in 1989 Portugal saw the introduction of an unemployment benefit for the first time; and Italy could also be said to be expanding its social protection net for the unemployed through the general upgrading of unemployment benefits. So the responses of the Scandinavian and southern countries to rising unemployment make them 'policy neighbours' to some extent.

Looking at developments around unemployment benefits over the decade, a conclusion about major change would be inappropriate. Benefits for the unemployed are certainly being rolled back but the basic national structures of provision remain as they were, with a few exceptions, as does the general crossnational picture. So European welfare states, with the exceptions of Greece and Italy, still organize the provision for their unemployed through a mixture of insurance and welfare principles, with insurance-based benefits during an initial period of unemployment followed by means-tested assistance should the unemployment persist. And there is no convergence between the insurance-oriented and welfare-oriented systems. That is, when under pressure insurance-based systems tend to tie their benefits closer to labour market participation while the systems which rely more on a welfare principle, such as Ireland and the United Kingdom, have strengthened this element of their provision (see also Reissert, 1994). So the general structures of and differ- ences in provision for the unemployed could be said to be holding fast.

The costs of caring: changes in the provisions around caring in the last ten years

Whether understood as relating to children or to elderly and ill people, providing and needing care is turning out to be one of the most dynamic areas in European social policy. The range of measures at the disposal of welfare states in respect of caring is relatively large but they can basically be thought of as oriented to the supply of services, either public or private. For a long time, if welfare states had a policy on caring, the public supply of caring-related services was the key dimension. But in the last decade or so, policy attention in Europe has turned much more closely to the private, nonmarket supply of services.

From the standpoint of policy, and also to some extent in the academic literature, caring for children has been distinguished from that of caring for ill or elderly people. ${ }^{5}$ For the analytic purpose of identifying the most important recent policy changes, it is helpful to retain that distinction.

\section{Measures related to caring for children}

Two types of provision are relevant here: benefits in relation to birth and maternity; benefits for the care of young children. Since maternity provisions derive their roots from other concerns - the health and welfare of mother and child, the labour market rights of women - they are not generally revelatory of how caring for children is treated by welfare states. Yet, it is still interesting to note that in none of our 16 countries, with the exceptions of the United Kingdom and to a lesser extent Sweden, have maternity benefits been significantly altered in 
Table 3 Main trends in parental leave during the last decade ${ }^{a}$

\begin{tabular}{|c|c|}
\hline Austria & $\begin{array}{l}\text { Parental leave (available to mothers who can fulfil the necessary waiting period for } \\
\text { unemployment benefits) was in } 1990 \text { prolonged until the child's second birthday; the yearly } \\
\text { adjustment of this flat-rate payment was reduced in } 1994 \text { and } 1995 \text {; since } 1993 \text { a maximum of } \\
4 \text { insurance years per child are to be counted as pension credits for the rearing of small } \\
\text { children. }\end{array}$ \\
\hline$\overline{\text { Belgium }}$ & $\begin{array}{l}\text { Career breaks for caring purposes have been possible since } 1985 \text {; these were extended to the } \\
\text { private sector in } 1993 \text {. }\end{array}$ \\
\hline Denmark & $\begin{array}{l}\text { Paid childcare leave was introduced in the public sector in 1984; it was extended with full pay } \\
\text { to the private sector in } 1995 \text {; in } 1995 \text { the replacement rate was reduced from } 80 \% \text { to } 70 \% \text { and } \\
\text { it is to be further reduced to } 60 \% \text { in } 1997 \text {; a childcare guarantee (for children 1-5) was made } \\
\text { in } 1993 \text { and came into effect in } 1996 .\end{array}$ \\
\hline Finland & $\begin{array}{l}\text { A child homecare allowance was introduced in } 1985 \text { and extended to all parents with a child } \\
\text { under } 3 \text { in } 1989 \text {; in } 1985 \text { every child under } 3 \text { got the right to municipal daycare; since } 1990 \\
\text { parents of a child under } 3 \text { have had a right to choose between public and homecare. }\end{array}$ \\
\hline France & $\begin{array}{l}\text { Paid leave was introduced in } 1985 \text { for families with } 3+\text { children; it was extended in } 1994 \text { to } \\
\text { families with } 2+\text { children. }\end{array}$ \\
\hline Germany & $\begin{array}{l}\text { Paid leave was introduced in } 1986 \text { (including pension credits); the duration of leave and of } \\
\text { credits was extended to } 2 \text { years in 1993; a right to nursery school for all children promised in } \\
1992 \text { took effect from 1996; the entire period of paid leave was made income-tested in } 1994 \\
\text { (instead of the last } 18 \text { months); the period of child-rearing credited for pension purposes was } \\
\text { increased from } 1 \text { to } 3 \text { years per child for children born after } 1991 \text {. }\end{array}$ \\
\hline Greece & Up to 2 years of unpaid maternal leave was introduced in 1992 for public-sector workers. \\
\hline Ireland & \\
\hline Italy & There have been extensions of the paid leave provision to different categories of employees. \\
\hline \multicolumn{2}{|c|}{ Luxembourg A } \\
\hline Netherlands & $\begin{array}{l}\text { In } 1991 \text { part-time leave for up to } 6 \text { months for each parent was introduced, only for } \\
\text { government-sector employees is the leave guaranteed to be paid. }\end{array}$ \\
\hline Norway & $\begin{array}{l}\text { In } 1992 / 3 \text { a 'time account' system was introduced, allowing reduced working hours and } \\
\text { flexibility in arranging paid leave and work; in the same period a coordination was undertaken } \\
\text { of the leave scheme to combine maternity, paternity and parental leaves; max. period of paid } \\
\text { leave raised to } 52 \text { weeks (at } 80 \% \text { of wage or } 42 \text { weeks at } 100 \% \text { of wages), } 4 \text { weeks of the total } \\
\text { leave are reserved for fathers. }\end{array}$ \\
\hline Portugal & Unpaid leave of 6-24 months per family was introduced in 1985. \\
\hline Spain & \\
\hline Sweden & $\begin{array}{l}\text { The duration of leave entitled through parental insurance was increased in } 1990 \text { to } 15 \text { months; } \\
\text { replacement rates for parental insurance were cut in } 1994,1995 \text { and } 1996 \text {; since } 1995 \text { at least } \\
\text { one month of parental leave cannot be assumed by the other parent. }\end{array}$ \\
\hline
\end{tabular}

Note: a Changes such as uprating of the benefits and minor alterations in either the conditions of entitlement or administration/delivery are not included here.

recent years. Nor have cash benefits to support families with children changed very much. In fact it is parental leave which has been the source of the most significant, and widespread, developments relating to how the state configures caring for children. Table 3 shows that all but a handful of countries have seen developments around parental leave in the last 10 years. The measures, while far from uniform, allow themselves to be grouped into three patterns: major new policy initiatives; extensions to existing policy; no relevant policy measures enacted. 
Two countries have undertaken major policy innovations around paying for parental caring in the last decade: Germany and France. Each has seen the introduction of what is within the national context a new departure in benefit type and in the case of Germany the subsidization of an activity which was formerly more or less privatized within the family. While the details of the benefits, especially conditions of access, tend to vary from country to country, at least one identifiable line of similarity crosses national borders. The benefits lack embeddedness within the national pattern of welfare: the low and flatrate payment renders these provisions quite unusual within benefit systems which are classically earnings-related. The second identifiable policy trend is of countries extending their existing policy arrangements to facilitate parental caring of young children. Judged quantitatively, this is by far the most dominant trend across Europe with the following 11 countries showing such a trend: Austria, Belgium, Denmark, Finland, Greece, Italy, Luxembourg, the Netherlands, Norway, Portugal and Sweden (Badelt and Bittner, 1995; Björnberg and Byörk Eydal, 1995; Ditch, 1996; Leira, 1996). But this is by no means a uniform grouping of countries, the nature of the measures undertaken and the overall constellation of policies fragment the 11 into a number of subgroups. So, in comparison to the Scandinavian countries of Denmark, Norway and Sweden where leave is not only paid but the wage replacement level high (if falling), Austria, Belgium, Luxembourg and the Netherlands offer only quite a limited payment, while parental leave in Greece and Portugal is unpaid. The third grouping of countries consists of those with no policy development around parental leave - Ireland, Spain and the United Kingdom. Social programmes in these nations have been unaffected by the move towards the institutionalization of a right of parents to some financial compensation from the state for taking care of their young children, although Spain at least has a statutory provision for unpaid parental leave.

Looked at overall, one could identify a trend in European welfare states towards a greater subsidization of parental caring of young children. As of 1995, 10 of our 16 nations were prepared to make a payment to the caring parent. To the extent that we can speak of crossnational convergence, it is a convergence around a two-sided trend. On the one hand there is a movement towards a generally lowlevel, conditional payment; on the other hand, the quality of social rights attaching to caring is being improved through ancillary protection measures for the care providers, such as labour market and (often basic) pension recognition. Looked at geographically, some developments appear to be congruent with existing typologies of welfare states. For example, of the six countries without a paid parental leave all except Luxembourg are either in the southern group of welfare states (which tend anyway to have a heavy reliance on the family) or in the liberal rim (the United Kingdom and Ireland, where the degree of state support for families is limited). However, the degree of exceptionalism is high. For example the moves under way in Germany and France towards paid parental leave appear to bring them closer to the Scandinavian pattern, although the low and conditional nature of the payment maintains a distance between them and Scandinavian practices. A further grouping includes the Netherlands, Belgium and Italy which appear unwilling to financially subsidize parental caring to a significant degree.

\section{Caring for elderly, ill and disabled people}

The caring needs of elderly people as well as those of incapacitated or ill adults and children have also caught the attention of policymakers (see Table 4). But this form of care has less often been a focus of cash benefit policy over the last 10 years than family care of young children. Greece, the Netherlands, Portugal and Spain have seen no major developments in this policy field over the period. 
Table 4 Main trends in cash benefits for caring for elderly, ill or disabled people during the last decade $^{a}$

\begin{tabular}{|c|c|}
\hline Austria & $\begin{array}{l}\text { An allowance payable to all elderly persons requiring care, graduated according to the degree } \\
\text { of care needed, was introduced in } 1993 .\end{array}$ \\
\hline Belgium & $\begin{array}{l}\text { A career break has been possible (in the context of unemployment insurance) for persons } \\
\text { wishing to provide care to ill or elderly people since } 1985 \text {; this was further extended in terms } \\
\text { of conditions and coverage in } 1991 \text { and } 1994 \text {. }\end{array}$ \\
\hline Denmark & $\begin{array}{l}\text { In } 1990 \text {, parents of seriously ill children under } 14 \text { gained a right to receive allowances if they } \\
\text { leave their jobs entirely or part time; in } 1990 \text { also a care allowance was introduced for those } \\
\text { who wish to care for dying relatives at home. }\end{array}$ \\
\hline Finland & $\begin{array}{l}\text { Homecare allowance for the person providing the care was introduced nationally in } 1991 \text {; } \\
\text { access tightened in } 1993 \text { (spouses excluded); pension access for carers was introduced in } 1993 .\end{array}$ \\
\hline France & $\begin{array}{l}\text { A 'trial' scheme was introduced in } 1995 \text { in } 12 \text { départements, consisting of a means-tested } \\
\text { payment to both the persons requiring care and those giving it. }\end{array}$ \\
\hline Germany & $\begin{array}{l}\text { A payment to the person receiving care, graduated according to the degree of care needed, was } \\
\text { introduced in } 1995 \text { under the auspices of social insurance. }\end{array}$ \\
\hline Greece & \\
\hline Ireland & $\begin{array}{l}\text { A means-tested payment for the person providing care was introduced in 1990; pension credits } \\
\text { for carers were introduced in } 1994 \text { and the number of years spent caring for children, elderly, } \\
\text { ill or incapacitated persons was disregarded for the purposes of calculating the number of } \\
\text { qualifying years for a full pension. }\end{array}$ \\
\hline Italy & $\begin{array}{l}\text { In } 1988 \text {, the non-means-tested payments to the person requiring care were extended to include } \\
\text { the non-self-sufficient elderly (they were formerly limited to working-aged, disabled people); } \\
\text { pension credits for carers were introduced in } 1994 \text {. }\end{array}$ \\
\hline Luxembourg & $\begin{array}{l}\text { An allowance to the person requiring care was introduced in } 1989 \text { and increased in value in } \\
1993 \text { and } 1994 .\end{array}$ \\
\hline \multicolumn{2}{|l|}{ Netherlands - } \\
\hline Norway & In 1992 those providing care were granted credits for entitlement to the additional pension. \\
\hline Portugal & \\
\hline Spain & \\
\hline Sweden & $\begin{array}{l}\text { In } 1989 \text { a paid leave (of } 30 \text { days) to care for an elderly family member was introduced; in } 1994 \\
\text { disabled persons got new rights to services and care, noteworthy among which is the right to } \\
\text { 'personal assistance'. }\end{array}$ \\
\hline $\begin{array}{l}\text { United } \\
\text { Kingdom }\end{array}$ & $\begin{array}{l}\text { In } 1985 / 6 \text { (following an appeal to the European Court of Justice) married women became } \\
\text { eligible for the flat-rate allowance which had, since } 1975 \text {, been paid to people (other than } \\
\text { married women) providing a certain amount of care to ill, elderly, and incapacitated persons. }\end{array}$ \\
\hline
\end{tabular}

Note: ${ }^{a}$ Changes such as uprating of the benefits and minor alterations in either the conditions of entitlement or administration/delivery are not included here.

These nations are now exceptional in Western Europe, however, where the trend is towards the state subsidization of the private and personal/informal care of elderly, ill and other incapacitated people. Austria, Denmark, Finland, Germany, Ireland and Luxembourg all saw new cash benefits for this purpose between 1985 and 1995. The developments in
Germany are of very deep significance. It has chosen to elevate need for care to the status of social insurance risk, thereby instituting the first new branch of social insurance in Germany since unemployment was incorporated as a social risk in 1927 . Of the remaining countries, Belgium, Italy, Sweden and the United Kingdom saw some extensions of exist- 
ing provisions over the period, whereas in France a new scheme was introduced on a pilot basis in a number of départements in 1995. While there is some tendency to adhere to the national policy logic when introducing payments for care, it would be wrong to overlook the exceptionalism of the developments. So to take an example, while needing care is now a social insurance risk in Germany, it is not covered under the normal German social insurance principles (with payments dependent upon the degree of incapacity rather than former wages). And in Scandinavia, especially Finland, some of the allowances paid for caring are considerably lower in value than is the norm in these still generous welfare states. Whatever the national exceptionalism, Evers (1994: 19) captures the cross-national trends with his remark that 'attendance allowances are no longer an unspecified add-on for people in need, but rather are specific tools for creating rights and appropriate steering mechanisms in a service and welfare society'.

But rights for whom? One of the many axes of variation (which from another angle could be viewed as policy dilemmas) surrounding cash benefits for caring is to whom the payment is made. During the last decade welfare states have been undecided about which arm of the relationship to support: the person requiring care or the person providing it. Of the six countries which have instituted new procedures, three (Austria, Germany and Luxembourg) have opted to make the payment to the person requiring care, whereas Denmark, Finland and Ireland have chosen to grant a cash benefit to the carer. ${ }^{6}$ The choice has potentially deep ramifications because in the first instance - making the payment to the person requiring care - welfare states are in effect distancing themselves from how the care needs are actually satisfied; whereas making the payment to the carer is a trend in the opposite direction - drawing more people within the direct embrace of the welfare state. To the extent that welfare states follow the first model, we could be seeing the emergence of a new type of welfare citizenship.
Given cross-national variations, the current trends around paying for care are not easily interpreted. The context within which these payments are being introduced is undoubtedly the key to whether they represent an expansion of the welfare state or a means of dismantling it. In Finland and the other Scandinavian countries, payments for personal caring, set within a context of a (still) widespread network of public care services, are poised between being a supplement to formal care and a move to transform the type of state support into cash rather than care. In Ireland, Britain, Germany and Austria among other countries, the payments are more identifiable as substitutes for formal care, either because of a lack of necessary public services or because of state withdrawal from providing them. So while they may not necessarily herald a new form of the welfare state, in almost all countries apart from Norway payments for care are being introduced or expanded in a context where the coverage of public services is declining and formal systems of welfare are experiencing increasing difficulty in meeting the need for care. The high degree of variation overall, in both existing arrangements and policy alterations, militates against any interpretation of convergence. In truth, there is no confluence in how European welfare states incorporate caring for adults as an activity meriting social rights. This is in some contrast to the treatment of caring for children around which there has been a more coherent set of policy developments over the last decade. The comparison tends to confirm the observation that caring for children and for adults are, in the eyes of most welfare states, rather different activities.

\section{Overview}

Even though the last decade is as arbitrary a period of study as any other, they have been a busy 10 years with some distinct results in terms of social policy patterns. Europe's preference for cutting social spending and tighten- 
ing access to benefits as a response to the "crisis' of welfare has led to a flurry of activity. While cut-backs may frame the overall context of change, retrenchment is an insufficient guide to how reforms have been pursued in practice. But mentioning retrenchment at this point is to jump too far ahead, for it is part of a wider discussion which bridges the gap between the largely descriptive analyses which I have undertaken here and how the changes under way can and should be analysed and interpreted. Three topics are key to this discussion: the identification and classification of welfare state reforms; the analysis of the impact of the changes; the interpretation of cross-national patterns. They each bespeak the need for clarity and precision.

Towards a classification of reforms, identifying the programme areas which have been most often singled out for policy action is a relatively easy first step. As we have seen, old-age pensions, unemployment and cash payments for caring have seen the most activity over the last decade. The general tenor of the reforms can also be described without great difficulty: cash benefits are getting meaner and their conditions harder to fulfil. It is less easy, though, to fit an analytic order on the reforms, although some criteria readily suggest themselves. One could differentiate between direct and indirect measures; alternatively one could distinguish one-off from cumulative measures; or reforms which focus on the 'big' as against the 'little' programmes. Target groups also offer a possible focus of analysis: for example the information presented above would support an interpretation of a shift in policy emphasis from the old to the young. But such categorizations on their own are deficient. Without an empirical and theoretical framework we are ill equipped to identify what constitutes a real change and which changes are significant. In other words, the reform process has to be anchored.

For this purpose, three things matter: the nature of the measures implemented; the time period involved; and the kind of system into which reforms are being introduced. As regards the nature of the reforms, retrenchment and other general terms such as austerity or cut-backs are of little or no help. They are for one thing too imprecise. They are furthermore incorrect in that certain areas of programme expansion are visible. And they are, finally, too unidimensional to capture the luxuriant complexity of the reforms which are under way. To settle now for such descriptive terms would be to short-change the scholarship on welfare state formation and expansion which has demonstrated so convincingly the significance of relatively small-scale variations. In any case, cut-backs come in many shapes and sizes. It can matter a lot whether policymakers choose to make across-the-board or selective cuts in benefit height, or to target particular groups, or to subject benefits to meanstests. In addition to the particular means of reform, the timescale of their implementation and the duration of their effect also matter. Reforms which at one point in time seem small scale and minor can have, either on their own or in association with other reforms, a very large cumulative effect. Pierson's (1994) differentiation between programmatic and systemic retrenchment usefully draws attention to how reforms undertaken today can map out the terrain and (intentionally or otherwise) constrain the leeway for future action. The third factor which is important in situating reforms is the type of welfare system within which the measures are implemented. A residualization or expansion of benefits or services can mean something very different in a universalist welfare state compared with one oriented towards minimum provision. All of this leads me to suggest that we have to configure a broad range of welfare state paths to economic and social change. We might begin to develop these in terms of paradigms of reform. Frank Castles (1994) is on the right track in identifying a number of policy responses. Although his particular fourfold categorization - abandonment, do nothing, adaptive, structural shifts - may not be to everyone's taste, it reminds us that welfare state reform encompasses durability and resilience as well as change. 
Considering their impact is another vital part of the interpretation of welfare state reforms. The nature of social rights is arguably one of the best points of reference for this purpose, provided that it is broadly conceptualized and appropriately operationalized. There are at least two vantage points from which social rights should be considered: individuals' guarantees from the state, and the principles underlying the welfare system itself. To determine how individual social rights are affected by reforms, identifying the winners and losers seems to me to be essential and for this there is no substitute for hard empirical evidence of whose benefits are affected by the reforms and how. The second type of impact - systemic impact has at least two interpretations. The first is in terms of the extent to which there is cost and responsibility shifting within different domains of the public support (cash, taxation and services) system and between the welfare state and other support institutions (market, family, community). In the latter regard, for example, many of the changes under way in European welfare states have the effect of pushing the onus of support back on the family, suggesting the need to integrate the family and the informal sector into the narrative of change. The second interpretation which can be put on systemic impact is the extent to which the basis of social provision itself is altered. The empirical identification of this is not so straightforward. As parts of the foregoing analysis demonstrate, institutional characteristics are not always revelatory of a change in social rights - in most countries there has been a disimprovement in people's social rights but the broad institutional features of welfare state programmes remain unchanged. Empirical indicators need to be pretty precise to pick up patterns such as emerging gaps in provision, increased waiting days, assumptions about means available from other sources - the very stuff of a disimprovement in social rights. In effect, there is no longer (if there ever was) a simple relationship between the principles of entitlement and the conditions of eligibility and our indicators should reflect that complexity.
The third level at which reforms have to be analysed is in terms of cross-national comparison. While there is movenıent towards greater selectivity and conditionality of benefits, one could not say that there is a widespread move away from social insurance per se. Instead a change is taking place within social insurance systems whereby the contribution and labour market-related preconditions for benefit entitlement are being strengthened. Social insurance benefits are thereby becoming more achievement-oriented. But there is little expansion of social insurance, and certainly none outside those systems which have always been heavily reliant on Bismarckian principles. The means-tested end of the continuum is growing though. The numbers here are being swollen on the one hand by the greater difficulty in qualifying for insurance benefits, and on the other hand by the growth of means-testing itself. To the extent that this is the case, one could hypothesize a trend of increasing polarization. The benefits for caring will probably exacerbate rather than ameliorate such a tendency given that they break with the existing principles of almost every system where they have been introduced. They are always special, either because receipt depends upon the investment of a specified type and amount of labour, because of the benefits' flat-rate or low-level nature, or for some other reason. The fact that caring benefits are not in the primary league of benefits - with some Scandinavian exceptions - increases their potential for gender polarization. However, a counter force to such polarization is the erosion in the quality of the conventional male benefits.

In regard to a comparative framework, the idea of regimes is helpful because it provides a measure of coherence in understanding how reforms are played out across nations. And there is some evidence of a regime logic in the current pattern of reform. Another key advantage of the regime approach is that it is a relatively rich source of hypotheses, not least about the reform potential of various kinds of welfare states. These advantages notwithstanding, the regime approach does not get us very far in identifying explanatory factors, and 
may even be misleading. For when it comes to explanations, the regime concept represents something of a 'cover-all-options' approach, encompassing as it does institutional characteristics, historical paths and legacies, structures of political organization and modes of integration, and the management of class, gender and race relations. So to talk about a regime logic probably widens rather than reduces the range of explanatory factors. The predominance of welfare state regimes in recent scholarship has also done us something of a disservice in fostering a relatively static view of welfare states and oversimplifying questions around development and change. The complexity and sociological richness of what is going on render debates about convergence or divergence in welfare states superficial and not very interesting.

The way forward lies in carefully designed studies which seek to identify diverse paths to reform and explain how these emerge and exert their influence. This work is still at an early stage and it should prove invigorating to discover just how continuity becomes change, change transition, and transition transformation.

\section{Notes}

To gather information on such a large number of countries is very difficult and I received help from a number of colleagues. I would like to thank Christoph Badelt, Ulla Bjornberg, Jet Bussemaker, Monique Kremer, Ann-Britt Mossberg, Maija Ojakoski, Liisa Rantalaiho, Chiara Saraceno, Kirsten Scheiwe, Birte Siim, Celia Valiente, Pascale Vielle and Karl Wörister. I especially thank Jens Borchert, Johan DeDeken and Axel WestPedersen for their always sound comments. An earlier version of this article was presented at the conference 'Engendering Citizenship, Work and Care' at Wassenaar in the Netherlands (July, 1996).

1 Were the last five years to be the period of enquiry rather than the last 10 , then sickness benefits would also be included among the programmatic areas which have been most targeted for reform. Similarly, if the focus were only on the five years from the mid to the end of the 1980 s means-tested social assistance benefits would have to have been singled out for particular attention.

2 One side-effect is that the concept of decommodification declines in relevance as an empirical indicator for comparative purposes.

3 Note that only schemes designated specifically for the unemployed - unemployment insurance and unemployment assistance - are considered here. General means-tested schemes, on which unemployed people rely considerably in some countries, are not included in the discussion.

4 Since educational leave also enables people to prolong their period of receipt of unemployment benefits, it is possible for Danes to remain in the unemployment insurance system from the age of 41 (even earlier if they are entitled to parental leave) until they reach the official pension age of 67 (Ploug and Kvist, 1994: 34).

5 This is sometimes reflected in administrative practice, with caring for children seen as falling within the remit of family policy whereas provisions for other forms of caring sit, usually uncomfortably, between a number of different policy domains.

6 However, note that in the case of Finland the new benefits are better understood as developing the second arm of the caring relationship since a series of payments for the person requiring care had already existed.

\section{References}

Badelt, C. and Bittner, B. (1995) 'Family Obligations in Austria', in J. Millar and A. Warman (eds) Defining Family Obligations in Europe, Bath Social Policy Papers No. 23, pp. 1-26. Bath: University of Bath.

Björnberg, U. and Byörk Eydal, G. (1995) 'Family Obligations in Sweden', in J. Millar and A. Warman (eds) Defining Family Obligations in Europe, Bath Social Policy Papers No. 23, pp. 359-78. Bath: University of Bath.

Burrows, R. and Loader, B. (eds) (1994) Towards a Post-Fordist Welfare State? London: Routledge.

Carter, J. and Rayner, M. (1996) 'The Curious Case of Post-Fordism and Welfare', Journal of Social Policy $25(3): 347-67$.

Castles, F. G. (1994) Testing the Limits of the Metaphor: Fordist and Post-Fordist Life Cycles in Australia and New Zealand, Australian National University Public Policy Programme Discussion Paper No. 40. Canberra: Australian National University.

Clasen, J. (1994) Paying the Jobless: a Comparison of Unemployment Benefit Policies in Great Britain and Germany. Aldershot: Avebury. 
Daly, M. (1997) 'Post What? Theorising Welfare State Change', Acta Sociologica, in press.

Ditch, J. (1996) Developments in National Family Policies in 1994. York: Social Policy Unit, University of York.

Esping-Andersen, G. (1990) The Three Worlds of Welfare Capitalism. Cambridge: Polity Press.

European Commission (1995) Social Protection in Europe. Luxembourg: Office for Official Publications of the European Communities.

Evers, A. (1994) 'Payments for Care: a Small but Significant Part of a Wider Debate', in A. Evers, M. Pijl and C. Ungerson (eds) Payments for Care: a Comparative Overview. pp. 19-41. Aldershot: Avebury.

Hagen, K. (1992) 'The Interaction of Welfare States and Labor Markets: the Institutional Level', in J. E. Kolberg (ed.) The Study of Welfare State Regimes, pp. 124-68. Armonk, NY: M. E. Sharpe.

Jessop, B. (1988) Conservative Regimes and the Transition to Post-Fordism: the Cases of Britain and West Germany, Essex Papers in Politics and Government No. 47. University of Essex.

Jessop, B., et al (1991) The Politics of Flexibility: Restructuring State and Industry in Britain, Germany and Scandinavia. London: Edward Elgar.

Leira, A. (1996) 'Family Obligations in Norway', in J.
Millar and A. Warman (eds) Defining Family Obligations in Europe, Bath Social Policy Papers No. 23, pp. 269-305. Bath: University of Bath.

Myles, J. (1990) 'States, Labour Markets and Life Cycles', in R. Friedland and A. F. Robertson (eds) Beyond the Marketplace: Rethinking Economy and Society, pp. 271-98. New York: de Gruyter.

Palme, J. (1990) Pension Rights in Welfare Capitalism: the Development of Old-age Pensions in $18 \mathrm{OECD}$ Countries 1930-85. Stockholm: Swedish Institute for Social Research.

Pierson, P. (1994) Dismantling the Welfare State? Reagan, Thatcher and the Politics of Retrenchment. Cambridge: Cambridge University Press.

Ploug, N. and Kvist, J. (eds) (1994) Recent Trends in Cash Benefits in Europe. Copenhagen: The Danish National Institute of Social Research.

Ploug, N. and Kvist, J. (1996) Social Security in Europe: Development or Dismantlement? The Hague: Kluwer Law International.

Reissert, B. (1994) 'Unemployment Compensation and the Labour Market: a European Perspective', in S. Mangan and L. Hantrais (eds) Unemployment, the Informal Economy and Entitlement to Benefits, Cross-national Papers, 3rd Series, pp. 7-21. Loughborough: European Research Centre, Loughborough University. 